\title{
PERAN KEPEMIMPINAN KEPALA SEKOLAH \\ DALAM PENGEMBANGAN BUDAYA SEKOLAH \\ DI SDN KWAYUHAN, KECAMATAN MINGGIR, SLEMAN
}

\author{
Haryani Diyati, Muhyadi \\ SD Negeri Sejati Moyudan Sleman, UNY \\ haryani.diyati.@yahoo.com, muhyadi@uny.ac.id
}

\begin{abstract}
Abstrak
Penelitian ini bertujuan untuk mengetahui: (1) peran kepemimpinan kepala sekolah dalam pengembangan budaya sekolah, (2) budaya yang berkembang di SDN Kwayuhan, dan (3) keefektifan budaya sekolah dalam usaha meningkatkan prestasi sekolah. Penelitian ini menggunakan pendekatan kualitatif dengan metode studi kasus. Subjek penelitian adalah kepala sekolah. Responden yang digunakan meliputi: guru, siswa, karyawan sekolah, ketua komite sekolah, dan Kepala UPT Pelayanan Pendidikan TK/SD Kecamatan Minggir. Teknik pengumpulan data adalah wawancara mendalam, pengamatan dan dokumentasi. Kredibilitas data diperoleh dengan cara pengamatan terus menerus selama tiga bulan, untuk klarifikasi dan pengecekan data dilakukan dengan triangulasi teknik dan sumber. Teknik analisis data adalah analisis interaktif. Prosedur penelitian meliputi pengumpulan data, reduksi data, penyajian data, dan verifikasi. Hasil penelitian menunjukkan bahwa peran kepemimpinan kepala sekolah dicapai dengan: (1) usaha menggerakkan warga sekolah dalam penyusunan kurikulum yang menjadi dasar dalam mengembangkan pendidikan, (2) menumbuhkan hubungan yang harmonis semua warga sekolah, (3) menciptakan kekompakan tim kerja, (4) menjaga komitmen warga sekolah, dan (5) melaksanakan supervisi klinis.
\end{abstract}

Kata kunci: kepemimpinan, budaya sekolah, prestasi sekolah

\section{THE ROLE OF SCHOOL PRINCIPAL ON THE SCHOOL CULTURAL DEVELOPMENT AT STATE ELEMENTARY SCHOOL KWAYUHAN, MINGGIR, SLEMAN SUBDISTRICT}

\begin{abstract}
This study is aimed to determine: (1) the role of the school principal in the school cultural development, (2) the culture that develops at State Elementary School Kwayuhan, and (3) the effectiveness of school culture as an effort to improve school performance. This research is qualitative approach with the case study method. The subjects were the school principal. Responden with: teachers, students, school employees, school committee chairman, and the Head of Kindergarten and Elementary Education Services Unit of Minggir Subdistrict. The data collection techniques used were interviews, observation, and documentation. The data credibility were obstained through three month observation and data clarification and checking was conducted with the source and technique triangulation. The data analysis used was interactive technique. The research procedures included data collection, data reduction, data presentation, and verification. The results of this study indicate that the role of the school principal is proved consistently and reached through: (1) efforts to move school members in constructing the curriculum for education development, (2) harmonious relationship all school members, (3) creating a solid teamwork, (4) the commitment of school members, (5) clinical supervision.
\end{abstract}

Keywords: school principal, school cultural, school achievement 


\section{Pendahuluan}

Peran Kepala sekolah sebagai seorang pemimpin pendidikan hendaknya dilakukan dengan penuh tanggung jawab. Dalam perspektif kebijakan pendidikan nasional kepala sekolah memiliki peran yang kuat dalam mengkoordinasikan, menggerakkan, dan menyerasikan semua sumber daya pendidikan yang tersedia.

Teori kepemimpinan bermanfaat bagi setiap pemimpin dalam menjalankan perannya sebagai seorang pemimpin pendidikan. Peranan kepala sekolah (Usman, 2011 p.277) sebagai pemimpin pendidikan antara lain: "(1) sebagai personal, (2) educator/pendidik, (3) manager, (4) administrator, (5) supervisor, (6) social, (7) leader, (8) entrepreneur, dan (9) climator/pencipta iklim kerja."

Kepemimpinan pendidikan mengandung dua pengertian, pendidikan yang berarti dalam hal apa dan dimana kepemimpinan berlangsung serta menjelaskan sifat dan ciri-ciri kepemimpinan. Pengertian yang kedua adalah kepemimpinan yang bersifat universal yang berlaku dan terdapat dalam berbagai bidang kehidupan manusia (Wahab, 2008 p.132).

Penjelasan dari pengertian kepemimpinan pendidikan yang pertama adalah kualitas kegiatan yang diintegrasikan dalam suasana pendidikan. Sehingga tujuan pendidikan yang telah ditetapkan oleh sekolah dapat tercapai secara efektif dan efisien. Sedangkan definisi yang kedua secara umum kepemimpinan diartikan sebagai suatu kemampuan seseorang dalam menggerakkan dan mengarahkan bahkan memaksa orang untuk berbuat sesuatu yang mengarah pada tercapainya suatu tujuan.

Dalam konteks pendidikan, pemimpin dapat melahirkan suatu kebijakan yang progresif dan visioner, mampu memastikan efektivitas dan produktivitas kebijakan yang diambil dengan suatu parameter yang jelas, mendorong bawahan dan mitra kerja untuk memahami visi dan misi tidak sekadar formalitas kegiatan tanpa memahami spirit nilai yang terkandung di dalamnya. Seorang pemimpin pendidikan tidak mentolerir kecurangan, distorsi, dan deviasi yang dilakukan bawahannya (Asmani, 2009 pp.106-107).

Sumidjo (2011 p.83) menyatakan bahwa "Kepala sekolah adalah seorang tenaga fungsional guru yang diberi tugas memimpin suatu sekolah di mana diselenggarakan proses belajar mengajar, atau tempat di mana terjadi interaksi antara guru yang memberi pelajaran dan murid yang menerima pelajaran."

Kepala sekolah bertanggung jawab atas penyelenggaraan sekolah. Pada sekolah yang berskala kecil kepala sekolah melaksanakan tugas sendiri tanpa bantuan orang lain. Bahkan disamping melaksanakan tugas kepala sekolah dia juga masih menjalankan peran dan bertugas sebagai pengajar. Kepala sekolah juga berperan untuk membangun jaringan dengan mitra kerja sekolah antara lain: komite sekolah, orang tua siswa, dan para pemangku kepentingan atau stakeholders.

Sebagai penanggung jawab pelaksanaan pendidikan, Starrat (2007 pp.16-18) menyatakan bahwa kepala sekolah merupakan agen berbagai komponen. Komponen pertama adalah negara. Kepala sekolah memiliki tanggung jawab untuk melaksanakan kebijakan dan haluan $\mathrm{Ne}-$ gara dalam mengupayakan pendidikan paling baik bagi anak-anak di sekolah. Komponen kedua adalah komunitas lokal yang bertugas melayani kebutuhan orang tua dan siswa. Tugas kepala sekolah adalah menganalisis berbagai macam kebutuhan. Komponen ketiga adalah para pendidik. Kepala sekolah bertanggung jawab terhadap peningkatan kualitas profesionalitas kerja para pendidik dan mengatasi permasalahan pendidikan baik yang ada di ruang kelas maupun di lingkungan sekolah. Selain itu kepala sekolah juga diharapkan mampu meng-apresiasi hasil karya para pendidik dan menyediakan kesempatan pengembangan profesi pendidik.

"Kepala sekolah berperan sebagai arbitrasi mediator, khususnya dalam menyelesaikan konflik internal maupun perbedaan pendapat di antara para anggotanya." (Wuradji, 2008 p.11). Kepala sekolah 
harus mampu menerjemahkan dan menerapkan kebijakan sehingga seluruh komponen dapat bekerja secara maksimal sesuai dengan tugasnya masing-masing. Kepala sekolah tidak berperan dan berfungsi secara efektif jika kebijakan yang diterapkan tidak memperhatikan kemajemukan kondisi komponen yang ada.

Dalam pengembangan budaya sekolah, Peterson \& Deal (Reinhartz \& Beach, 2004 p.212) menjelaskan bahwa kepala sekolah memiliki peran yang paling pokok. Kepala sekolah berperan mengkomunikasikan nilai-nilai, perilaku dan harapanharapan sekolah kepada seluruh warga sekolah. Tindakan kepala sekolah, ucapan, pesan-pesan, dan perilaku nonverbalnya sangat berpengaruh dalam membentuk budaya sekolah. Kepemimpinan pendidikan adalah kegiatan mempengaruhi pengikut dalam rangka mengembangkan dan memajukan sekolah. Di antara sejumlah peran kepemimpinan kepala sekolah yang menonjol adalah peran untuk membangun budaya sekolah. Tugas kepala sekolah adalah mengkomunikasikan nilai-nilai inti, perilaku dan harapan-harapan yang harus dijadikan landasan dalam bersikap dan berperilaku sehari-hari.

Data prasurvey yang dilakukan pada tanggal 26 Agustus 2013 diperoleh informasi, keberhasilan kepala sekolah SD Negeri Kwayuhan Minggir dalam mengembangkan budaya sekolah, indikasinya antara lain: (1) sebagian besar para siswa, guru, karyawan datang dan pulang tepat pada waktunya, (2) lingkungan sekolah tampak bersih, (3) setiap pagi guru bersalaman dengan siswa sebagai ungkapan budaya senyum, sapa, salam dan disiplin sekolah, (4) kebersihan lingkungan sekolah terawat, (5) tidak dijumpai guru maupun siswa terlambat, (6) sebelum belajar, seluruh siswa berdoa dipimpin oleh ketua kelasnya masing-masing, (6) selama 2 tahun berturut-turut menduduki peringkat 1 tingkat kecamatan Minggir dalam pencapaian nilai Ujian Nasional.

Berdasarkan wawancara awal dengan kepala SD Negeri Kwayuhan tanggal 26 Agustus 2013, ditemukan belum mak- simalnya pelaksanaan budaya sekolah, indikasinya: (1) pengunjung perpustakaan jumlahnya sedikit (antara empat sampai dengan lima siswa per hari), (2) sekolah belum memiliki rencana pengembangan budaya sekolah secara mandiri, (3) konsep pengembangan budaya sekolah sebagai upaya peningkatan prestasi pendidikan belum dipahami oleh seluruh warga sekolah (4) belum semua stakeholders menjalankan peran partisipasi dalam mengembangkan budaya sekolah, (5) belum semua warga sekolah menerapkan budaya sekolah secara konsisten

Dengan adanya permasalahan di atas, maka perlu diteliti pelaksanaan tugas kepala sekolah dalam perannya sebagai pemimpin pendidikan. Kepala sekolah sebagai motor penggerak peningkatan kualitas pendidikan di sekolah, perlu memahami cara-cara pembentukan dan pengelolaan budaya sekolah. Salah satu upaya yang dapat ditempuh adalah dengan merevitalisasi budaya sekolah yang bersumber pada nilai-nilai manajemen berbasis sekolah, etos kerja dan integritas seluruh elemen sekolah. Budaya sekolah diharapkan mampu memberikan kontribusi secara maksimal terhadap upaya peningkatan prestasi sekolah.

Budaya sekolah merupakan bagian dari budaya organisasi, merupakan kunci yang mendorong keberhasilan suatu organisasi. Hal tersebut dibuktikan oleh adanya sejarah pertumbuhan peradaban manusia. Salah satu faktor penentu keberhasilan dan keberlangsungan adalah kuat tidaknya peran kepemimpian dalam menciptakan budaya organisasi. Pada akhirnya budaya organisasi tersebut akan menentukan kualitas kerja.

Prestasi belajar siswa dapat diwujudkan dengan melalui budaya sekolah, peningkatan motivasi dan kepuasan kerja guru. Efek langsung dari sekolah yang telah menerapkan budaya sekolah yang kuat adalah (1) etos kerja warga sekolah meningkat, (2) iklim kerja kondusif, akrab dan stabil, (3) partisispasi warga sekolah dalam kegiatan peningkatan prestasi sekolah tinggi dan menyeluruh, (4) kepuasan 
kerja guru dan siswa tinggi, dan (5) pada akhirnya produktifitas hasil pendidikan meningkat. Salah satu konsep peningkatan kualitas adalah teori sekolah efektif yang lebih memfokuskan pada perbaikan proses pendidikan. Beberapa indikator yang menunjukkan karakter dari konsep peningkatan kualitas antara lain sebagai berikut: (1) lingkungan sekolah yang aman dan tertib, (2) sekolah memiliki misi dan target mutu yang ingin dicapai, (3) sekolah memiliki kepemimpinan yang kuat, (4) adanya harapan yang tinggi dari personel sekolah untuk berprestasi, (5) adanya pengembangan staf sekolah sesuai dengan tuntutan perkembangan ilmu dan teknologi, (6) adanya pelaksanaan evaluasi yang kontinyu dan dimanfaatkan sebagai penyempurnaan/perbaikan mutu, dan (7) adanya komunikasi dan dukungan intensif dari orang tua murid/masyarakat.

Indikator kepemimpinan sekolah efektif antara lain mampu menetapkan tujuan masa depan sekolah secara professional. Nilai, kepercayaan, sikap dan perilaku (merupakan komponen dari budaya sekolah) merupakan dasar bagi setiap kepemimpinan sekolah dalam menyusun dan melaksanakan program pengembangan sekolah.

\section{Metode Penelitian}

Jenis Penelitian

Penelitian ini mengunakan pendekatan kualitatif dengan metode studi kasus yang dirancang untuk menggali informasi tentang peran kepemimpinan dalam pengembangan budaya sekolah di SD Negeri Kwayuhan Kecamatan Minggir.

Tempat dan Waktu Penelitian

Penelitian ini dilaksanakan di SD Negeri Kwayuhan Kecamatan Minggir. Waktu penelitian dilaksanakan bulan September sampai Desember 2013.

Subjek Penelitian

Subyek penelitian ini adalah kepala sekolah. Sedangkan responden ditentukan menggunakan purposive sampling Dalam penelitian ini ditentukan: 6 orang guru kelas yang sudah mengajar lebih dari 2 tahun, 2 orang karyawan (dengan pendidikan minimal SMA), 3 orang siswa yang berprestasi di sekolah dengan prestasi akademik dan 3 orang siswa berprestasi nonakademik, ketua pengurus komite sekolah dan Kepala UPT Pelayanan Pendidikan Kecamatan Minggir Kabupaten Sleman, Daerah Istimewa Yogyakarta. Obyek penelitian adalah peran kepemimpinan kepala sekolah dalam pengembangan budaya sekolah di SD Negeri Kwayuhan Minggir

Teknik Pengumpulan Data dan Teknik Analisis Data

Teknik pengumpulan data yang digunakan penelitian ini adalah (1) wawancara mendalam, (2) pengamatan/pencermatan (3) dokumentasi. Instrumen pengumpulan data : (1) pedoman wawancara mendalam, (2) pedoman observasi, (4) blanko/format pengamatan, (5) blanko/ format hasil dokumentasi, (6) kamera.

Keabsahan data (terutama untuk mencari kredibilitas) dalam penelitian kualitatif ini diperoleh dengan cara: (1) pengamatan terus menerus selama 3 bulan, (2) triangulasi untuk melakukan klarifikasi dan pengecekan data.

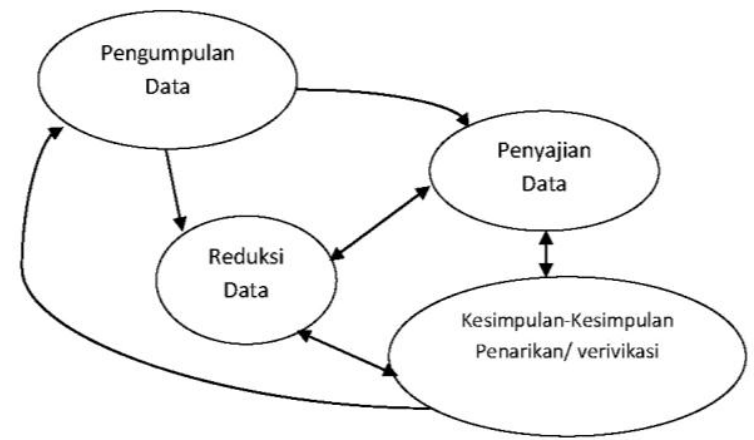

Gambar 1. Komponen Analisis Data

(Miles, M. B. \& Huberman, A. M.(1992: 20))

Teknik analisis data dalam penelitian ini menggunakan model interaktif, yakni: 1) Proses pengumpulan data, melalui observasi, wawancara dan dokumentasi yang dicatat dalam teks, 2) Reduksi data, merupakan proses menyeleksi, memfokuskan, menyederhanakan, meringkas, mengelompokkan data mentah dari temuan di 
lapangan dalam beberapa unit, 3) Proses penyajian data yaitu mendiskripsikan data yang sudah dikelompokkan sesuai dengan pokok bahasan, sementara itu penyajian data berbentuk naratif, tabel dan grafik dan 4) Penarikan kesimpulan,

\section{Hasil Penelitian dan Pembahasan}

Gambaran Budaya Sekolah SD Negeri

Kwayuhan Minggir

\section{Budaya Bersih pada Lingkungan Sekolah}

Pembiasaan budaya bersih yang ditanamkan pada siswa SD Negeri Kwayuhan tidak sekedar kegiatan temporal tetapi bersifat terus menerus dan terprogram. Hasilnya cukup memuaskan suasana lingkungan sekolah menjadi bersih, indah, dan menyenangkan.

Budaya bersih ditanamkan oleh sekolah melalui berbagai kegiatan. Antara lain dengan mengaktifkan piket kelas, lomba kebersihan antar kelas, dan penugasan penjaga sekolah pada bidang kebersihan. Kegiatan untuk kebersihan lingkungan makin terlihat ketika sekolah melaksanakan program lomba kebersihan kelas. Lomba semacam ini diadakan setiap akhir semester.

Budaya kebersihan lingkungan yang lainnya yang ditanamkan oleh sekolah adalah Jumat bersih. Semua siswa pada jam pelajaran pertama selama 15 menit setiap hari Jumat membersihkan kelas, halaman sekolah, taman di depan kelas dan lingkungan sekolah.

\section{Budaya Keagamaan}

Penanaman nilai-nilai beragama secara terus menerus dilakukan untuk membentuk watak dan karakter siswa. Hal ini diterapkan oleh sekolah dengan tujuan membentuk budi pekerti siswa. Seperti dinyatakan oleh Sukinem selaku kepala sekolah sebagai berikut.

"Dengan memprogramkan kegiatan sholat dzuhur berjamaah, untuk kelas VI ditambah dengan program sholat dhuha, dan mengarahkan semua siswa untuk berdoa sebelum melakukan sebuah kegiatan.Saya sering bercerita bahwa keberhasilan sese- orang tidak hanya dari usaha yang terlihat mata tetapi juga harus dilakukan dengan doa. Semakin banyak kita berdoa maka hati akan tenang dan tentram karena keberuntungan adalah sesuatu yang murni berasal dari Allah SWT." (SKN/21/10/2013)

Suasana keagamaan yang cukup tinggi di SD Negeri Kwayuhan terlihat ketika perayaan hari raya Qurban. Berdasarkan pengamatan pada tanggal 17 Oktober 2013, siswa tampak tekun mengikuti kegiatan penyembelihan hewan qurban. Penyembelihan dilakukan di sekolah lain mereka berpartisipasi dengan pembagian daging yang sudah masak. Kegiatan keagamaan yang dilakukan di sekolah dengan bimbingan dan pengawasan oleh guru agama antara lain: sholat Dzuhur berjamaah, sholat dhuha, dan Taman Pendidikan Alquran.

\section{Budaya disiplin dan tertib}

Tingkat kedisiplinan SD Negeri Kwayuhan cukup baik. Keteladanan kepala sekolah merupakan awal penanaman sikap disipilin dan tertib di sekolah. Setiap hari kepala sekolah hadir pada pukul 06.20. Mengontrol kebersihan kelas dan lingkungan sekolah adalah kegiatan pertama yang dilakukannya setelah sampai di sekolah.

Suri teladan yang baik dari kepala sekolah menjadi perhatian bagi siswa. Seperti dikemukakan oleh Yosep siswa kelas VI sebagai berikut.

"Bu S orangnya baik, suka menasehati siswa agar tertib dalam belajar. Tidak boleh terlambat ke sekolah, sekolah harus bersih. Bila kelas masih kotor saya belum dibolehkan masuk untuk belajar. Saya senang punya kepala sekaolah seperti Bu S." (YSP/15/11/2013)

Kegiatan kepala sekolah setelah mengontrol kebersihan sekolah adalah menyambut kehadiran siswa. Beliau berdiri di depan pintu kantor guru untuk menyalami siswa-siswa yang baru hadir dan akan memasuki kelas. Dengan kegiatan ini siswa yang terlambat menjadi malu kalau terlambat hadir di sekolah. Sehingga hampir setiap hari tidak ada siswa yang terlambat. 


\section{Budaya berprestasi}

Sekolah melaksanakan budaya berprestasi dengan tujuan untuk meningkatkan prestasi sekolah secara umum. Usaha yang ditempuh oleh sekolah antara lain dengan pemberian beasiswa bagi siswa yang berprestasi, pemberian hadiah bagi siswa yang berhasil menjuarai suatu lomba, mengadakan kegiatan lomba di bidang ilmu pengetahuan, seni, olahraga, kegiatan les, try out bagi siswa kelas VI, dan kegiatan perbaikan dan pengayaan.

Kegiatan lomba di sekolah tersebut diadakan setiap tahun sekali setelah siswa menyelesaikan THB semester genap dengan nama kegiatan lomba Porsenitas. Setiap kelas mengirimkan siswa yang ditunjuk dengan kemampuan yang dimiliki untuk maju mengikuti lomba. Dalam kegiatan ini siswa sangat bersemangat dan mengeluarkan kemampuannya untuk bersaing agar dapat meraih hadiah.

Tabel 1. Data Kejuaraan SDN Kwayuhan Minggir

\begin{tabular}{|c|c|c|c|}
\hline No & Jenis Lomba & Lembaga Penyelenggara & Hasil \\
\hline 1 & $\begin{array}{l}\text { Musabaqoh } \\
\text { Tilawatil Quran } \\
\text { (CCA }\end{array}$ & $\begin{array}{l}\text { Dinas Pendidikan Kab. } \\
\text { Sleman. Tahun } 2006\end{array}$ & $\begin{array}{l}\text { Juara Harapan } \\
\text { II }\end{array}$ \\
\hline 2 & $\begin{array}{l}\text { CCA Alkitab } \\
\text { Bulan Kitab Suci } \\
\text { Nasional }\end{array}$ & $\begin{array}{l}\text { UPT Pelayanan } \\
\text { Pendidikan Kec. Minggir } \\
\text { Tahun } 2006\end{array}$ & Juara I dan II \\
\hline 3 & $\begin{array}{l}\text { FKK SD } \\
\text { Kerajinan Tangan }\end{array}$ & $\begin{array}{l}\text { Kec. Minggir Tahun } \\
2007\end{array}$ & Juara I \\
\hline 4 & $\begin{array}{l}\text { FKK SD } \\
\text { Kerajinan Tangan }\end{array}$ & Kab. Sleman Tahun 2007 & Juara II \\
\hline 5 & $\begin{array}{l}\text { Melukis Tipe B } \\
\text { Putra }\end{array}$ & $\begin{array}{l}\text { Kec. Minggir Tahun } \\
2008\end{array}$ & Juara II \\
\hline 6 & Olimpiade IPA & $\begin{array}{l}\text { Kec. Minggir Tahun } \\
2009\end{array}$ & Juara II \\
\hline 7 & $\begin{array}{l}\text { Olimpiade } \\
\text { Matematika }\end{array}$ & $\begin{array}{l}\text { Kec. Minggir Tahun } \\
2009\end{array}$ & Juara III \\
\hline 8 & Siswa Berprestasi & $\begin{array}{l}\text { Kec. Minggir Tahun } \\
2009\end{array}$ & Juara V \\
\hline 9 & $\begin{array}{l}\text { Pencapaian Nilai } \\
\text { UN }\end{array}$ & $\begin{array}{l}\text { Kec. Minggir Tahun } \\
2009\end{array}$ & Peringkat III \\
\hline 10 & $\begin{array}{l}\text { OLIMPIADE } \\
\text { MIPA Jalur C }\end{array}$ & $\begin{array}{l}\text { Kec. Minggir Tahun } \\
2010\end{array}$ & Juara V \\
\hline 11 & $\begin{array}{l}\text { Pencapaian Nilai } \\
\text { UN }\end{array}$ & $\begin{array}{l}\text { Kec. Minggir Tahun } \\
2010\end{array}$ & Peringkat I \\
\hline 12 & $\begin{array}{l}\text { Pencapaian Nilai } \\
\text { UN }\end{array}$ & $\begin{array}{l}\text { Kec. Minggir Tahun } \\
2011\end{array}$ & Peringkat IV \\
\hline 13 & $\begin{array}{l}\text { Olimpioade } \\
\text { MIPA }\end{array}$ & $\begin{array}{l}\text { Kec. Minggir Tahun } \\
2012\end{array}$ & Juara IV dan V \\
\hline 14 & $\begin{array}{l}\text { Pencapaian Nilai } \\
\text { UN }\end{array}$ & $\begin{array}{l}\text { Kec. Minggir Tahun } \\
2012\end{array}$ & Peringkat I \\
\hline 15 & $\begin{array}{l}\text { Olimpiade MIPA } \\
\text { Jalur C }\end{array}$ & $\begin{array}{l}\text { Kec. Minggir Tahun } \\
2013\end{array}$ & Juara II \\
\hline 16 & Seni Tari & $\begin{array}{l}\text { Kec. Minggir Tahun } \\
2013\end{array}$ & Juara II \\
\hline 17 & $\begin{array}{l}\text { Pencapaian Nilai } \\
\text { UN }\end{array}$ & $\begin{array}{l}\text { Kec. Minggir Tahun } \\
2013\end{array}$ & Peringkat I \\
\hline
\end{tabular}

Siswa yang berprestasi di sekolah akan diikutkan pada lomba di tingkat kecamatan dan kabupaten. Sehingga siswa yang dikirim merasa bangga mewakili sekolahnya sekaligus senang dengan hadiah yang diperolehnya. Seperti dikemukakan oleh Hamdani siswa kelas V berikut ini.

"Saya senang mengikuti lomba di sekolah dan di kecamatan. Karena selain mendapat hadiah, kalau dapat juara hati saya senang dan bangga. Teman-teman juga menjadi senang dan bangga karena sekolahku menjadi terkenal di kecamatan Minggir ini." (HDN/15/11/2013)

\section{Budaya Membaca}

Untuk mendukung program gemar membaca sekolah melakukan berbagai usaha, antara lain menjalin kerjasama dengan perpustakaan daerah kabupaten Sleman melalui program perpustakaan keliling. Mobil perpustakaan keliling datang ke sekolah tiap dua minggu sekali.

Sekolah juga membuat program pengembangan minat baca yang dilakukan dengan melaksanakan kegiatan lomba minat baca, mengarahkan siswa untuk rajin membaca di perpustakaan, dan mengusahakan agar ruang perpustakaan selalu bersih, nyaman, dan buku tertata rapi.

Pengembangan budaya membaca terkendala oleh kurangnya buku-buku perpustakaan dan waktu untuk melayani peminjaman buku. Seperti dikemukakan oleh Rupini guru yang mendapat tugas tambahan sebagai pengelola perpustakaan seperti berikut.

"Karena saya mengajar waktu untuk melayani siswa pada jam istirahat. Kadangkadang waktu istirahat yang digunakan untuk berkunjung ke perpustakaan tidak digunakan dengan baik oleh siswa, mereka cenderung untuk bermain dan jajan ke warung. Untuk siswa kelas rendah bukubukunya masih kurang karena buku yang ada lebih tepat dibaca oleh siswa kelas atas." (RPN/29/10/2013)

Selain kegiatan peningkatan minat baca siswa sekolah berusaha melengkapi jumlah buku yang ada di perpustakaan sedikit demi sedikit dengan menyisihkan uang dari dana BOS. 


\section{Budaya Iklim Kerja Kondusif}

Pengembangan budaya iklim kerja kondusif bagi para siswa dilaksanakan dengan kegiatan kemah bersama di setiap akhir semester. Pada kegiatan ini sekolah berupaya mendidik siswa agar saling membantu dan bekerja sama. Hasilnya cukup baik para siswa memiliki rasa kesetiakawanan dan tidak egois.

Budaya senyum, sapa dan salam semakin tertanam melalui kegiatan penyambutan kehadiran para siswa oleh guru dan kepala sekolah setiap pagi dengan bersalaman di depan ruang guru. Sehingga keakraban diantara siswa, guru dan kepala sekolah terbina dengan baik.

Hasil pembiasaan senyum, sapa dan salam tampak pada beberapa siswa pada hari Jumat 15 November 2013. Para siswa tersebut mengucapkan salam sambil mengulurkan tangannya untuk bersalaman dengan seorang guru. Hal ini menunjukkan rasa hormat siswa pada gurunya.

Hubungan yang harmonis antar guru terlihat pada jam istirahat. Kepala sekolah dan semua guru maupun karyawan berkumpul di ruang guru. Suasana di kantor guru tampak akrab dan menyenangkan. Bila ada seorang guru berhalangan hadir maka mereka akan saling menolong dengan cara menggantikan tugasnya mengajar di kelas. Mereka melaksanakan hal ini dengan suka rela. Mereka berbincangbincang sambil menikmati minuman dan snek. Keakraban antara semua warga sekolah dapat terwujud dengan adanya pertemuan pada jam istirahat ini.

Dalam perbincangan tersebut kadang-kadang dimanfaatkan oleh beberapa guru untuk mengulas permasalahan yang terjadi di kelasnya, seperti kenakalan siswa dan kemajuan belajar siswa.

Peran Kepala Sekolah dalam

Mengembangkan Budaya Sekolah

Peran sebagai Personal

Sukinem adalah kepala sekolah SD

Negeri Kwayuhan Minggir sejak bulan April 2007. Pendidikan terakhir adalah sarjana Pendidikan Jurusan Pendidikan Sejarah.
S (Sukinem) memiliki akhlak yang baik, mampu menjadi teladan bagi warga sekolah, integritasnya baik, bersifat terbuka, mampu mengendalikan diri, bakatnya sebagai pemimpin tampak dalam pergaulan sehari-hari, ramah dan mampu bergaul dengan siapa saja. Seperti dikatakan oleh Rusman salah seorang karyawan sekolah sebagai berikut.

"Beliau sangat sabar, lemah lembut tetapi cukup tegas bila menghadapi anak buah. Apabila ada guru atau karyawan yang berbeda pendapat maka beliau akan berusaha untuk meyakinkan bahwa pendapat guru atau karyawan tersebut tidak tepat. Kesabaran yang beliau tunjukkan menimbulkan rasa segan dan membuat guru atau karyawan menjadi sadar akan tugas dan kwajibannya di sekolah." (RSM/14/ 10/2013)

Sukinem memiliki integritas kepribadian sebagai pemimpin, loyalitas dan disiplin terhadap pekerjaan sangat baik. Beliau datang di sekolah paling awal dan pulang paling akhir. Hasil pengamatan pada tanggal 9 Oktober 2013 S datang di sekolah pukul 06.35. Beliau datang kemudian berjalan mengamati kebersihan kelas dan semua ruangan.

Sebagai kepala sekolah Sukinem memiliki keinginan yang kuat. Hal ini ditunjukkan dengan perhatiannya yang cermat terhadap permasalahan yang timbul di sekolah. S selalu mengadakan pengecekan terhadap pekerjaan yang dilakukan karyawan tata usaha, guru dan penjaga sekolah. Untuk mengontrol kinerja guru dan karyawan Sukinem mengadakan supervisi dua kali dalam satu semester. Kegiatan ini menunjukkan bahwa Sukinem konsisten terhadap program pengembangan budaya tertib dan disiplin di sekolah. Berikut adalah penjelasan Sri Marzuniah seorang guru di SDN Kwayuhan.

"Kami disupervisi dua kali dalam satu semester. Beliau masuk ke kelas saya memperhatikan proses pembelajaran yang saya lakukan. Setelah pembelajaran selesai beliau mngajak saya berbincang-bincang tentang pembelajaran yang baru terjadi. Kami merasa senang karena kami diper- 
hatikan, tidak ada perasaan tertekan atas supervisi yang beliau laksanakan. Setiap pagi beliau berjalan mengelilingi lingkungan sekolah untuk mengontrol kebersihan, bila melihat keadaan sekitar kelas dan teras masih kotor tidak segan- segan beliau akan menyapunya." (SMZ/14/10/ 2013)

\section{Peran sebagai Pendidik}

Sebagai pendidik Sukinem berperan dalam mengembangkan budaya sekolah. Sukinem bersama para guru menyambut kedatangan siswa dengan berdiri di depan ruang guru untuk bersalaman, saling sapa dan tersenyum. Kegiatan ini bertujuan untuk mendorong siswa datang tepat waktu di sekolah, tertib dalam berpakaian dan untuk menumbuhkan sikap saling hormat.

Sebagai kepala sekolah Sukinem menanamkan budaya tegur, sapa, senyum dan salam pada semua warga sekolah. Setelah cara ini diterapkan maka pelanggaran tata tertib dapat berkurang. Siswa menjadi sadar untuk mentaati tata tertib di sekolah bukan karena dimarahi oleh gurunya.

Sebagai kepala sekolah Sukinem juga sebagai guru mata pelajaran PKn. Usaha usaha yang dilakukan oleh Sukinem sebagai seorang pendidik adalah menanamkan akhlak mulia pada semua warga sekolah. Hal ini terlihat dari ketekunannya dalam melaksanakan ibadah sholat dan pengamalan akidah agama Islam lainnya. Sukinem memberikan teladan ketekunan beribadah, dan mengembangkan sikap toleransi terhadap agama lain. Seperti dikatakan oleh Sri Marzuniah sebagai guru pendidikan agama Islam berikut.

"Bu S meiliki sifat agamis yang tinggi, selalu mengajarkan pada siswa untuk memulai segala kegiatan dengan berdoa. Beliau juga rajin menjalankan ibadah sholat. Setiap hari beliau ikut berjamaah dzuhur di sekolah bersama para guru dan siswa yang beragama Islam. Kalau sudah selesai mengikuti pembelajaran di kelas maka bu $S$ akan segera membimbing para siswa untuk berwudhu dan bersiap-siap untuk sholat dzuhur berjamaah." (SMZ/ 14/10/2013)

Keteladanan Sukinem sebagai pendidik ternyata dapat membangkitkan motivasi siswa untuk mengembangkan budaya sekolah, yang meliputi budaya bersih, disiplin, dan tertib. Sebagai pendidik Sukinem mampu menjadi contoh bagaimana seharusnya orang bertindak.

Hal ini sesuai dengan pendapat Saring selaku kepala UPT pelayanan pendidikan kecamatan Minggir, bahwa budaya sekolah akan berhasil jika faktor keteladanan dan kepemimpinan kepala sekolah dapat dijalankan. Kepala sekolah sebagai figur yang utama di sekolah harus dapat memberikan contoh teladan dalam tindakan, ucapan dan pikirannya. Seperti dijelaskan Saring sebagai berikut.

"Dalam mengembangkan budaya sekolah diperlukan keteladanan dari kepala sekolah. Karena budaya sekolah dapat dibangun dari sebuah keteladanan yang dilakukan secara terus menerus. Bagaimana kepala sekolah mampu mengelola sekolahnya misalnya bila ada guru atau karyawan sekolah yang indisipliner. Jangan hanya marah-marah tetapi ada tindakan yang tegas. Mengembangkan budaya sekolah memang tidak mudah. Diperlukan usaha terus menerus dan berkeinambungan." (SRG/26/11/2013)

Peran sebagai Manajer

Sebagai seorang manajer Sukinem selalu berusaha untuk menciptakan iklim kerja sekolah kondusif. Iklim kerja di SDN Kwayuhan ditandai oleh adanya keakraban dan persaudaraan.

Sehingga iklim kerja berkembang baik dan kodusif. Seperti dikemukakan oleh Suwarni salah seorang guru sebagai berikut.

"Setiap hari Sabtu setelah jam mengajar selesai, semua guru dan karyawan berkumpul di ruang guru untuk membicarakan permasalahan yang timbul dalam kegiatan pembelajaran yang telah dilakukan. Kepala sekolah memberikan tanggapan dan berusaha untuk mecarikan solusi dengan bertanya pada guru yang 
lain. Sebulan sekali kepala sekolah juga mengadakan rapat evaluasi atas segala suatu progam sejauh mana keberhasilannya. Dalam kesempatan ini kepala sekolah memberikan bimbingan dan arahan pada semua guru dan karyawan agar senantiasa saling bantu, saling dukung dan saling menghormati."(SWN/29/10/2013)

Sebagai manajer SDN Kwayuhan Sukinem berupaya agar sekolah menjalin hubungan yang baik dengan masyarakat di lingkungan sekolah. Upaya yang dilakukan dengan membentuk forum komite sekolah. Forum komite yang dibentuk dengan tujuan untuk mencari dukungan ide dan pemikiran, mengefektifkan sumber belajar, menggali sumber dana, dan mengefektifkan peran peminat pendidikan. Hal ini disebabkan minat masyarakat untuk menyekolahkan anaknya di SDN Kwayuhan kurang. Seperti dikemukakan oleh Parjinem salah seorang guru.

"Ada kecenderungan orang tua untuk menyekolahkan anaknya di yayasan dengan alasan untuk menghidupkan atau melestarikan yayasan dalam golongan agama masing-masing. Orang tua yang beragama Islam lebih memilih sekolah Muhammadiyah, yang beragama Kristen memilih sekolah BOPKRI dan yang beragama Katolik memilih sekolah Kanisius. Hal ini terjadi pada orang tua yang bertaraf ekonomi menengah ke atas. Akibatnya siswa yang bersekolah di sini adalah siswa yang orang tuanya tidak mampu." (PJN/21/10/2013)

Pertemuan sekolah dengan komite sekolah dilaksanakan sebanyak dua kali dalam setahun. Sukinem percaya jika budaya sekolah dapat berkembang dengan baik jika sekolah, orangtua, guru, dan siswa bekejasama dengan baik. Peran Sukinem sebagai manajer adalah menyatukan semua unsur tersebut dalam mencapai tujuan sekolah. Berikut penjelasan Mujiyono ketua komite SDN Kwayuhan.

"Selama 28 tahun saya menjadi anggota pengurus komite di sekolah ini, saya dapat melihat bahwa kepemimpinan bu $S$ sangat baik. Sejauh ini bila sekolah akan mengadakan suatu kegiatan selaku kepala sekolah beliau mengundang saya untuk diminta pendapat dan saran. Dan setelah kegiatan selesai beliau akan mengkonfirmasikan segala sesuatunya. Saya juga sering diajak untuk mengevaluasi kegiatan-kegiatan yang dilakukan oleh sekolah, apakah sebuah kegiatan baik untuk dilanjutkan atau harus dihentikan. Kepala sekolah selalu berkomunikasi dengan komite dan transparan dalam pengelolaan sekolah termasuk pengelolaan keuangan terutama dalam penggunaan dana BOS." (MJY/01/11/ 2013)

\section{Peran sebagai Administrator}

Sebagai administrator Sukinem berusaha menertibkan sistem administrasi sekolah, mulai dari administrasi kesiswaan, sarana dan prasarana, kurikulum, keuangan, perpustakaan dan administrasi hubungan masyarakat. Berikut adalah penjelasan Sukinem tentang tugasnya sebagai administrator.

"Administrasi sekolah dan data-data yang
didindingkan saya kerjakan bersama
dengan tenaga Tata Usaha dan dibantu
oleh bebrapa guru akhirnya dapat dileng-
kapi. Sering saya melakukan pengarahan/
dialog dan pemantauan pelaksanaan pem-
belajaran yang dilakukan oleh para guru.
Setelah semua berjalan baik saya tinggal
memantau dan melakuakn evaluasi.'
(SKN/21/10/2013)

Meskipun belum semua administrasi sekolah dapat terselesaikan dengan baik, sebagian besar telah berhasil disusun ke dalam RPPS yang merupakan induk dari semua program pengembangan sekolah. RPPS menjadi dasar program kerja sekolah terdiri dari visi misi sekolah, rencana strategi lima tahun ke depan, rencana operasional sekolah untuk satu tahun ke depan. Dari RPPS Tim pengembang menyusun program kerja.

Berdasarkan pengamatan pada hari Rabu tanggal 4 Desember 2013, administrasi yang telah dikelola oleh Sukinem meliputi Rencana Pengembangan Sekolah (RPS), Program Jangka Panjang, Program jangka pendek, Program tahunan, Program pengembangan kurikulum, Program kesis- 
waan, Program administrasi, Program administrasi sarana prasarana, Rencana anggaran keuangan sekolah, Program hubungan masyarakat, Program kebersihan lingkungan. Berdasarkan pengamatan yang dilakukan tersebut administrasiadministrasi tersebut lengkap dan terdokumentasi secara baik.

Peran sebagai Supervisor

Supervisi yang dilakukan secara rutin oleh Sukinem adalah supervisi kunjungan kelas. Supervisi kunjungan kelas dilaksanakan oleh Sukinem untuk mengetahui kemajuan kegiatan belajar mengajar, suasana kompetisi siswa yang sehat dan ilmiah dua kali dalam setiap semester. Hasil supervisi ditindaklanjuti oleh Sukinem dengan mendiskusikan hasil pengamatan. Pendekatan supervisi klinis digunakan oleh Sukinem untuk memecahkan masalah yang terjadi dalam kegiatan belajar mengajar. Dapat diartikan bahwa supervisi yang dilakukan bertujuan untuk memecahkan permasalahan bersama antara guru dan kepala sekolah.

Pelaksanaan disiplin dan tata tertib sekolah disupervisi setiap waktu. Dimulai pada pukul 06.30 sampai kegiatan sekolah berakhir. Sukinem melaksanakan supervisi sendiri dan juga mengembangkan juga pola supervisi teman sejawat dalam pengawasan disiplin dan ketertiban sekolah. Pelaksanaan kegiatan supervisi teman sejawat dilakukan dengan memberi tanggung jawab kepada koordinator urusan kegiatan masing-masing, memberi tanggung jawab kepada ketua kelas untuk mengontrol ketertiban kelas masingmasing. Secara periodik hasil supervisi dilaporkan kepada kepala sekolah untuk ditentukan tindak lanjutnya.

Setiap hari Sukinem melakukan supervisi untuk memantau pelaksanaan budaya bersih. Berdasarkan pengamatan pada hari Rabu, tanggal 9 Oktober 2013, Sukinem datang di sekolah pada pukul 06.35. Pekerjaan yang pertama dilakukannya adalah melakukan cek kebersihan lingkungan sekolah. Kalau ditemukan kelas atau halaman sekolah masih kotor, beliau akan segera memanggil siswa atau penjaga sekolah untuk membersihkannya.

\section{Peran sebagai Pemimpin}

Sebagai pemimpin Sukinem berusaha melibatkan semua pihak dalam semua pekerjaan. Gaya partisipatif ini dapat membangkitkan motivasi guru, karyawan, dan siswa untuk mencapai cita-cita bersama. Seperti penjelasan Saring kepala UPT Yandik Kecamatan Minggir sebagai berikut.

"Kepala sekolah akan berhasil jika ia bisa bekerja sama dengan semua stakeholders sekolah. Meskipun mampu secara pribadi tetapi kepala sekolah jangan bekerja sendiri. Untuk memmotivasi guru, karyawan, dan siswa harus dikembangkan budaya penghargaan dan pemberian sanksi. Guru, karyawan, dan siswa akan merasa dihargai apabila disapa atau diberi pujian atas hasil kerjanya. Tetapi apabila mereka melanggar suatu aturan juga harus diberi teguran atau hukuman sesuai ketentuan. Yang paling penting kepala sekolah akan berhasil apabila semua warga sekolah dapat bekerja sesuai dengan tugasnya masingmasing." (SRG/26/11/2013)

Sukinem mengembangkan gaya kepemimipinan yang berorientasi pada tugas dan manusia. Dari gaya kepemimpinan ini semangat kerja siswa, guru, dan karyawan SDN Kwayuhan lebih meningkat. Kedua gaya kepemimpinan tersebut diterapkan secara tepat dan fleksibel sesuai dengan kondisi dan kebutuhan. Mereka bekerja dalam iklim kerja yang kondusif, akrab, dan menyenangkan.

\section{Peran sebagai Wirausahawan}

Beberapa program inovatif yang diluncurkan oleh Sukinem telah berhasil. Maksudnya sebagian guru, siswa, dan karyawan sekolah dapat menerima dan memberikan dukungannya. Akan tetapi ada beberapa orang guru, karyawan, dan siswa yang sudah terbiasa dengan keadaan lama merasa keberatan dengan penerapan hal-hal yang baru. Hal ini merupakan suatu hambatan yang harus ditangani secara serius. Seperti dijelaskan oleh Sukinem sebagai berikut. 
"Saya mempunyai target secara akademik maupaun non akademik. Pencapaiannya dengan melihat kemampuan siswa untuk diajar dan dilatih secara maksimal dan kemampuan guru sebagai pengajar dan pelatih yang mumpuni. Dalam bidang olahraga saya berusaha untuk mengadakan alat-alat seperti lapangan tenis meja, net untuk volley yang saya usahakan secara person karena keuangan sekolah tidak mencukupi. Dalam bidang keagamaan saya minta sama guru agama untuk melatih siswa secara intensif terutama dalam mengahadapi lomba." (SKN/29/10/2013)

Pernyataan di atas membuktikan bahwa Sukinem memiliki jiwa pantang menyerah, bekerja keras dalam mencapai keberhasilan sekolah. Hal ini selaras dengan jiwa kewirausahaan. Sukinem selalu memotivasi guru, karyawan, dan siswa agar dapat melaksanakan tugasnya dengan semangat kerja yang tinggi.

Jiwa pantang menyerah dan selalu mencari solusi yang terbaik dalam menghadapi kendala dikembangkan oleh Sukinem secara serius. Di antara gedung lama dan gedung baru dimanfaatkan untuk membuat laboratorium alam dengan enam buah buis beton ditanami beraneka macam tanaman air, dan tanah yang masih kosong dimanfaatkan sebagai kebun sekolah ditanami pohon pisang dan pohon mangga. Walaupun tidak besar laboratorium dan kebun sekolah ini digunakan oleh Sukinem untuk mengembangkan kreativitas siswa. Laboratorium alam digunakan untuk praktek pembelajaran IPA, dengan sarana ini guru dan siswa dapat hemat waktu tidak perlu keluar lingkungan sekolah. Sedangkan kebun sekolah menghasilkan buah pisang dan buah mangga yang dapat dijual dan hasilnya dapat digunakan sebagai uang tambahan bagi sekolah. Kadang-kadang buah pisang dimanfaatkan oleh guru dan siswa dalam praktek pembelajaran PKK.

Dampak nyata peran Sukinem ini tampak pada data penerimaan siswa baru. Walaupun tidak mengalami kenaikan secara mencolok tetapi sekolah mampu bertahan dari persaingan dan menjadi sekolah yang berprestasi di tingkat kecamatan Minggir.

\section{Peran sebagai Pencipta Iklim Kerja Kondusif}

Menurut penjelasan Sukinem, upaya menciptakan iklim kerja yang kondusif dilakukan dengan berbagai cara, antara lain: meningkatkan iklim kerjasama yang baik dengan berbagai pihak, berpartisipasi dalam kegiatan sosial masyarakat, memupuk kepekaan sosial terhadap orang atau kelompok yang lain, menciptakan suasana kerja yang sehat dan menyenangkan.

Iklim kerja yang tumbuh secara sehat akan mempermudah upaya pencapaian tujuan sekolah, yaitu peningkatan prestasi sekolah secara akademik dan nonakademik. Seperti dijelaskan oleh Saring kepala UPT Yandik kecamatan Minggir berikut.

"Yang perlu diperhatikan adalah kebersamaan semua warga sekolah untuk mencapai goal atau tujuan yang diharapkan oleh sekolah yang bersangkutan. Kepala sekolah harus mampu mengarahkan dan mengajak semua warga sekolah untuk bertanggung jawab terhadap pelaksanaan program sekolah. Tanggung jawab semua warga sekolah akan membentuk sebuah komitmen yang berawal dengan terbinanya iklim kerja yang sehat dan kondusif. Ini merupakan salah satu peran kepala sekolah untuk menciptakan iklim kerja yang sehat sehingga prestasi sekolah akan meningkat." (SRG/26/11/2013)

Berdasarkan hasil wawancara tersebut dapat disimpulkan bahwa iklim kerja merupakan roh dari seluruh pekerjaan yang ada di suatu sekolah. Iklim kerja bukanlah menjadi tujuan suatu sekolah, tetapi jika iklim kerja yang kondusif dapat diciptakan maka tujuan sekolah akan mudah tercapai.

Faktor- Faktor yang Berpengaruh

Terhadap Budaya Sekolah SDN Kwayuhan

Faktor Pendukung

1. Visi dan misi sekolah

Visi dan misi sekolah tersebut dipajang di setiap ruangan sekolah. Hal dilakukan dengan tujuan agar semua warga sekolah sadar dan ingat akan tujuan mereka berada dan bekerja di sekolah. 
Visi dan misi sekolah disusun berdasarkan kebutuhan dan cita-cita realistis sekolah. Visi SDN Kwayuhaan adalah "Mandiri, unggul dalam prestasi berlandaskan iman dan taqwaserta sehat dan santun". Sedangkan misi SDN Kwayuhan adalah" Melaksanakan MPMBS; melaksanakan pembelajaran PAKEM; mengembangkan pembelajaran life skill; mengembangkan bakat, minat, kreativitas, dan kompetensi; melestarikan nilai-nilai luhur adat, sosial, budaya, seni dan agama; melestarikan wawasan nusantara; melestarikan karakteristik adat dan sosial budaya lokal; menyesuaikan dengan perkembangan ilmu pengetahuan dan wawasan global".

Visi dan misi sekolah tersebut dipajang di setiap ruangan sekolah. Hal dilakukan dengan tujuan agar semua warga sekolah sadar dan ingat akan tujuan mereka berada dan bekerja di sekolah. Orang lain yang masuk ke sekolah pun dapat mengetahui arah pelaksanaan pengembangan pendidikan di SDN Kwayuhan. Visi SDN Kwayuhan mendorong adanya budaya kompetitif yang positif bagi setiap warga sekolah yang meliputi guru, karyawan, dan siswa. Motivasi kompetitif semakin kuat karena ditempuh melalui budaya iman dan taqwa dan bersumber pada budaya lokal.

Visi dan misi sekolah menjadi dasar bagi penyusunan program peningkatan prestasi sekolah.

\section{Hubungan Harmonis Antar Warga Sekolah}

Iklim kerja sekolah yang kondusif, menyenangkan, dan penuh persaudaraan juga merupakan faktor pendukung program pengembangan budaya sekolah. Pengembangan budaya sekolah yang dilakukan oleh Sukinem menghasilkan suasana iklim kerja SDN Kwayuhan tampak harmonis, dan penuh persaudaraan. Pada waktu pengamatan pada tanggal 10 Oktober 2013, suasana kantor guru pada jam istirahat tampak hangat dan penuh persahatan. Semua guru tampak riang dan terlihat saling bersenda gurau. Sukinem sebagai kepala sekolah membaur diantara mereka dalam suasana gembira.

\section{Kurikulum Sekolah}

Kurikulum sekolah disusun oleh Tim Pengembang Kurikulum. Kurikulum tersebut disusun berdasarkan kebutuhan dan kemampuan yang ada di sekolah. Masukan-masukan dari warga sekolah yang terdiri dari guru, karyawan, dan siswa ditampung dan diolah sehingga menjadi kurikulum yang dapat mengekspresikan kebutuhan dan cita-cita sekolah. Kurikulum tersebut disebut sebagai kurikulum tingkat satuan pendidikan (KTSP) SDN Kwayuhan. Berikut pernyataan Bakir salah seorang guru.

"Kami masih menggunakan kurikulum KTSP. Dalam menyusun kurikulum kami bersama kepala sekolah menyusun tim yang terdiri dari guru dan komite sekolah. Tim yang dibentuk berusaha untuk menentukan orientasi kurikulum pada kebutuhan dan kemampuan sekolah." (BKR/14/ 10/2013)

Dengan kurikulum KTSP SDN Kwayuhan dapat diketahui bahwa KTSP tersebut telah mendorong pengembangan budaya sekolah yang berorientasi pada budaya lokal dan budaya internasional yang diperlukan siswa.

\section{Proses Pembelajaran}

Sekolah berusaha menerapkan pendekatan pembelajaran yang berorientasi pada keadaan lingkungan sekolah. Suasana pembelajaran yang aktif, kondusif dan menyenangkan sangat mendukung pengembangan budaya kompetitif, budaya ilmiah, dan budaya disiplin bagi siswa. Berdasarkan hasil pengamatan tersebut diketahui bahwa proses pembelajaran dilaksanakan secara aktif, kreatif dan menyenangkan. Motivasi belajar siswa yang tinggi tampak ketika jam pelajaran Matematika berakhir dan berganti dengan jam istirahat. Mereka masih berada di kelas dan masih melihat-lihat nilai yang diperolehnya dari pelajaran Matematika. Hal ini tampak juga pada proses pembelajaran di kelas V dan VI. Pembelajaran IPA sangat menarik bagi siswa karena di dalam pembelajaran tersebut dapat terlihat kreativitas dan keterampilan siswa dalam melakukan berbagai kegiatan seperti diskusi 
dan pengamatan pada obyek yang sedang dipelajari. Antusiasme siswa tampak ketika kegiatan diskusi kelas mereka beradu argumentasi hasil pengamatan yang telah mereka lakukan.

\section{Faktor Penghambat}

1. Kepribadian Negatif Guru dan Siswa Meskipun Sukinem telah menerapkan gaya kepemimpinan partisipatif, transparan, akuntabilitas dan mengutamakan keteladanan tetapi hambatan tetap ada. Ada beberapa guru dan siswa yang belum dapat bersikap disiplin. Perilaku tidak disiplin yang terlihat ketika pengamatan adalah adanya dua orang guru dan seorang karyawan yang tidak mengikuti upacara di halaman sekolah. Keterlambatan siswa datang ke sekolah juga merupakan contoh ketidakdisiplinan.

Kepribadian negatif yang lain adalah lemahnya minat baca siswa. Ketika dilakukan pengamatan tampak sebagian besar siswa lebih suka memanfaatkan waktu istirahat untuk makan-makan di kantin. Sikap seperti inilah yang menghambat pelaksanaan budaya membaca.

\section{Minimnya Sumber Dana}

Selama ini pendapatan diperoleh dari dana BOS saja. Minimnya sumber dana menjadi salah satu kendala untuk pengembangan prestasi sekolah.

Banyak program pengembangan budaya sekolah tidak dapat diwujudkan. Misalnya program untuk memasang konblok di halaman sekolah terpaksa dibatalkan karena tidak ada dana pendamping dari masyarakat dan orang tua siswa.

Akibat terbatasnya sumber dana sekolah belum mampu memberikan kesejahteraan yang layak bagi guru dan karyawan. Rata-rata honor guru dan karyawan tidak tetap sebesar Rp 200.000,00. Minimnya gaji tersebut berakibat pada pelaksanaan pengembangan budaya tertib dan disiplin.

\section{Kurangnya Sarana dan Prasarana Pembelajaran}

Sekolah belum mempunyai tempat sholat khusus atau Mushola. Ruangan kelas yang digunakan sebagai tempat sholat pada pagi hari dipakai untuk kegiatan
PAUD (Pendidikan Anak Usia Dini); ruang laboratorium IPA sekaligus digunakan sebagai tempat penyimpanan alat peraga IPS dan Bahasa Indonesia. Dengan kondisi ruangan seperti diatas tentu saja menghambat efektifitas pelaksanaan budaya keagamaan dan proses pembelajaran IPA.

Pengembangan budaya sekolah di SDN Kwayuhan sebagai salah satu upaya untuk meningkatkan prestasi sekolah. Kepala sekolah sadar bahwa budaya sekolah merupakan kunci utama keberhasilan sekolah dalam mencapai tujuan.

Perencanaan, pelaksanaan, dan evaluasi program pengembangan budaya sekolah menjadi satu dengan program kurikulum, kesiswaan, sarana dan prasarana, ketenagaan, dan keuangan. Sehingga berakibat sekolah tidak dapat mengevaluasi secara pasti tentang pelaksanaan program pengembangan budaya sekolah. Evaluasi yang dilaksanakan melalui laporan pelaksanaan program sekolah secara keseluruhan. Keberhasilan dan kegagalan pengembangan budaya sekolah tidak terindikasi dengan baik sehingga kurang mendapat perhatian dari sekolah.

Meski demikian keadaan budaya sekolah di SDN Kwayuhan secara umum berkembang dengan baik. Budaya iklim kerja kondusif berhasil diwujudkan. Suasana hubungan semua warga sekolah tampak hangat, kondusif, dan penuh persaudaraan. Keyakinan Sukinem adalah bahwa budaya sekolah akan berkembang dan tumbuh dengan subur apabila setiap warga sekolah mampu menciptakan iklim kerja yang kondusif, tenang, dan menyenangkan; hubungan yang harmonis dilandasi keterbukaan, partisipatif, dan persuasif merupakan salah satu strategi dalam pengembangan budaya sekolah; lebih mengutamakan keteladanan daripada memberi instruksi.

Keberhasilan pengembangan budaya iklim kerja kondusif berakibat terhadap budaya bersih, budaya disiplin, dan budaya keaagamaan dapat berkembang dengan baik. Budaya sekolah yang belum dapat berkembang dengan baik adalah budaya membaca. Hal ini disebabkan 
belum ada tenaga pengelola dan bukubuku perpustakaan yang ada banyak yang sudah rusak. Akibatnya siswa tidak dapat terlayani keperluannya untuk membaca atau meminjam buku di perpustakaan.

Budaya berprestasi secara akademis maupun nonakademis masih kurang. Meskipun dapat meraih peringkat pertama se kecamatan Minggir dalam pencapaian nilai ujian nasional tetapi untuk prestasi yang lain masih berada pada peringkat bawah. Kejuaraan yang diperoleh masih sebatas tingkat kecamatan belum sampai ke tingkat kabupaten.

Untuk mengatasi berbagai kendala tersebut, Sukinem selaku kepala sekolah berusaha menanamkan budaya sekolah melalui keteladanan berpikir, berbicara, dan bertingkah laku. Budaya keteladanan ini tidak hanya terfokus pada dirinya sebagai kepala sekolah, Sukinem berharap agar setiap warga sekolah mampu memberikan keteladanan pada warga yang lain.

Berdasarkan pengamatan dan analisis, pelaksanaan program budaya sekolah di SDN Kwayuhan dengan metode keteladanan membutuhkan waktu yang lama. Jika menemukan warga sekolah yang belum mampu melakukan dan mendukung pelaksanaan budaya sekolah, maka warga sekolah yang lain harus bersabar, mengutamakan persaudaraan, hingga akhirnya iklim kerja kondusif dapat dipertahankan.

Sikap keteladanan kepala sekolah secara terus menerus dilaksanakan. Hasil yang dapat dicapai belum dapat disimpulkan dengan pasti. Maksudnya, keberhasilan budaya sekolah mengalami pasang surut. Suatu waktu warga sekolah telah mampu melaksanakan budaya sekolah dengan baik, tetapi di hari yang lain masih dtemukan pelanggaran. Dengan pendekatan keteladanan budaya sekolah dapat berkembang dengan kuat dan tumbuh karena dorongan intrinsik.

Melalui keteladan kepala sekolah berperan sebagai personal, pendidik, manajer, administrator, supervisor, pemimpin, innovator, entrepreneur/kewirausahaan, dan pencipta iklim kerja. Sukinem melakukan peran tersebut secara simultan, dan saling dukung. Setiap gaya kepemimpinan diterapkan sesuai dengan situasi dan kondisi sekolah. Sehingga sifat kepemimpinan yang terbuka, partisipatif dapatdipertanggungjawabkan sebagai kata kunci pelaksanaan peran kepemimpinan.

Peran sebagai pendidik dilaksanakan oleh Sukinem antara lain dengan kemampuan mengajar mata pelajaran PKn kelas IV, V, VI dan menampilkan diri sebagai warga sekolah yang berakhlak mulia. Akhlak mulia tersebut tampak dari kebiasaan Sukinem yang rajin menuaikan ibadah sholat. Sukinem selalu mengajak siswa, guru, dan karyawan melaksanakan sholat dzuhur berjamaah. Tetapi tidak semua warga sekolah mengikuti ajakannya. Ternyata pola keteladanan akhlak mulia tidak cukup dengan tindakan keteladanan. Karena siswa masih dalam usia anak-anak pola instruksi perlu dilaksanakan bersamaan dengan pola keteladanan. Sebagian besar siswa belum mampu menangkap semangat ketekunan Sukinem sebagai keteladanan hidup beragama.

Peran Sukinem sebagai pendidik yang lain adalah memberi contoh bagaimana seseorang harus melakukan disiplin kerja atas kemauan sendiri, bukan karena peran kepengawasan dari atasan. Sukinem datang paling awal dan pulang paling akhir. Pola keteladanan ini berpengaruh terhadap kedisiplinan guru dan siswa. Namun, muncul kesan bahwa Sukinem terlalu lunak terhadap siswa, guru, dan karyawan yang terlamabat. Akibatnya sampai saat ini masih dijumpai warga sekolah yang terlambat. Pola keteladanan tetap efektif tetapi tindakan tegas untuk sebagian warga sekolah tampaknya lebih efektif lagi.

Peran pendidik sekaligus mengefektifkan peran manajer. Peran manajer Sukinem pada hakekatnya adalah proses merencanakan, mengorganisasikan, melaksanakan, memimpin, dan mengendalikan kegiatan sehingga tujuan sekolah dapat tercapai secara efektif dan efisien. Strategi yang ditempuh Sukinem adalah kerja tim dan pelibatan seluruh komponen sekolah. Kekompakan tim kerja menyebabkan seko- 
lah menjadi kuat dan eksis meskipun hidup di tengah persaingan yang ketat.

Peran manajer $S$ dilengkapi dengan peran administrator. Sukinem berusaha mengadministrasikan seluruh kegiatan pengembangan budaya sekolah dalam dokumen program. Administrasi sekolah yang telah berhasil disusun Sukinem bersama tim kerjanya adalah administrasi kepegawaian, kurikulum, dan kesiswaan.

$S$ mengembangkan budaya disiplin melalui kegiatan kebersihan dan keindahan sekolah. Beliau tidak segan-segan memberi contoh bagaimana cara menyapu, membersihkan jendela, teras sekolah, dan halaman sekolah. Keteladanan ini dapat mengubah kebiasaan warga sekolah. Warga sekolah dapat mengikuti jejak Sukinem, semua warga sekolah berusaha menjaga kebersihan sekolah mulai dari sebelum pelajaran sampai jam pelajaran terakhir. Hal ini tampak ketika mengamati kebersihan sekolah pada hari dan jam yang berbeda (pada pagi, siang, dengan hari dan bulan berbeda) sekolah tampak selalu bersih. Sebagian besar siswa membuang sampah pada tempatnya.

Untuk mengetahui terlaksana tidaknya program, kepala sekolah secara rutin menerima laporan dan memberikan solusi pada kasus-kasus yang terjadi setiap sebulan sekali dalam suasana rapat koordinasi sekolah. Meskipun sekolah belum melakukan tindak lanjut dari hasil evaluasi rapat tersebut. Kepala sekolah belum membudayakan penghargaan dan hukuman. Akibatnya belum semua warga sekolah dapat melaksanakan budaya sekolaah secara konsisten dan terus menerus.

Peran lain yang dilaksanakan oleh Sukinem selaku kepala sekolah dalam mengembangkan budaya sekolah adalah peran kepemimpinan partisipatif, keterbukaan dan akuntabilitas. Dalam melaksanakan tugas kegiatan Sukinem berusaha melibatkan guru, karyawan, dan siswa sesuai dengan kemampuan dan tugasnya masing-masing. Peran ini ternyata sangat efektif karena semua warga sekolah pada akhirnya dapat bertanggung jawab secara penuh terhadap sukses dan tidaknya program sekolah. Sikap apatis dapat diminimalisir, warga sekolah merasa puas bekerja karena diberi peran dan tanggung jawab.

Sikap warga sekolah tersebut membawa dampak positif. Kecurigaan antar warga sekolah terhadap pelaksanaan kegiatan, dan keuangan sekolah dapat dikurangi. Dengan menampilkan laporan keuangan sekolah di papan pengumuman, warga sekolah dapat mengetahui pertanggung jawaban keuangan oleh tim pelaksana. Komponen sekolah yang lain juga dapat mengetahui kemampuan terakhir keuangan sekolah. Sehingga bila terjadi kekurangan semua pihak dapat memahami, bahkan berusaha memberikan masukan bagaimana cara menyelesaikan permasalahannya.

Peran kepala sekolah dalam pelaksanaan supervisi klinis tidak laangsung menunjuk kesalahan,memberikan instruksi, tetapi berusaha melibatkan guru sebagai pelaku utama pada kegiatan belajar mengajar dalam memecahkan suatu masalah. Peran klinis ini ternyata berdampak positif pada program pengembangan budaya iklim kerja kondusif. Suasana sekolah tetap tenang meskipun banyak permasalahan yang terjadi. Hal ini terjadi karena tidak ada saling salah menyalahkan, yang ada adalah sikap bagaimana setiap warga sekolah menganalisis serta menentukan solusinya. Masalah yang berat menjadi ringan karena dikerjakan bersama dalam suasana tenang dan menyenangkan.

Dengan kenyataan tersebut dapat disimpulkan bahwa keberhasilan pengembangan budaya sekolah di SD Kwayuhan memerlukan waktu yang lama. Peran kepala sekolah sebagai personal, pendidik, manajer, administrator, supervisor, pemimpin, kewirausahaan, dan pencipta iklim kerja perlu terus menerus diterapkan dan ditingkatkan sejalan dengan sifat budaya sekolah yang berkembang dan hidup terus menerus seiring dengan hidup dan berkembangnya manusia. 


\section{Simpulan dan Saran}

Simpulan

Dari data yang diperoleh setelah dianalisis maka kesimpulannya adalah sebagai berikut:

1. Keberhasilan kepala SDN Kwayuhan dalam menjalankan peran kepemimpinannya dicapai dengan: (a) usaha menggerakkan semua warga sekolah dalam penyusunan kurikulum yang menjadi dasar dalam mengembangkan pendidikan, (b) menumbuhkan hubungan yang harmonis semua warga sekolah, (c) menciptakan kekompakan tim kerja, (d) menjaga komitmen warga sekolah, dan (e) melaksanakan supervisi klinis secara rutin. Keadaan ini menunjukkan bahwa peran kepemimpinan kepala sekolah di SDN Kwayuhan berhasil dengan baik.

2. Peran kepemimpinan kepala SDN Kwayuhan dalam mengembangkan budaya sekolah secara umum cukup baik. Budaya sekolah dikembangkan melalui: iklim kerja kondusif, disiplin kerja, budaya bersih, dan budaya keagamaan. Sehingga budaya berprestasi dapat diwujudkan pada prestasi yang diraih dalam pencapaian nilai Ujian Nasional berada pada peringkat pertama se kecamatan Minggir.

3. Fungsi pengembangan budaya sekolah untuk meningkatkan prestasi sekolah di SD Negeri Kwayuhan dilaksanakan dengan: (1) menciptakan lingkungan sekolah bersih; (2) meningkatkan kedisiplinan warga sekolah, (3) mendorong penerapan nilai-nilai agama, (4) menciptakan suasana kompetitif, (5) menciptakan iklim kerja kondusif dan harmonis, (6) menciptakan kepemimpinan yang kuat yang dibangun atas dasar keterbukaan, dan akuntabilitas.

\section{Saran}

Saran dari hasil penelitian ini adalah:

1. Strategi reward and punishment hendaknya dilaksanakan oleh kepala sekolah SDN Kwayuhan dalam menjalankan peran keteladanan secara konsisten
2. Program pengembangan budaya sekolah seyogyanya disusun secara mandiri terpisah dengan program sekolah yang lain. Disusun dengan indikator pencapaian yang jelas sehingga dapat dilaksanakan dan dievaluasi secara efektif.

3. Pengembangan budaya sekolah di SDN Kwayuhan belum dapat dievaluasi secara efektif karena kepala sekolah belum merencanakan program pengembangan budaya sekolah secara ekspilist. Program pengembangan budaya sekolah hanya diiintegrasikan pada program kerja sekolah yang lain. Sekolah seyogyanya membentuk tim pengembang budaya sekolah yang bertugas menyusun, mengkoordiasikan, melaksanakan, dan mengevaluasi program pengembangan budaya sekolah.

\section{DAFTAR PUSTAKA}

Asmani, J. M. (2009). Manajemen pengelolaan dan kepemimpinan pendidikan professional. Yogyakarta: Diva Press

Miles, M. B., \& Huberman, A. M. (1992). Qualitative data analysis. London: Sage Publication (Terjemahan Tjetjep Rohendi Rohidi) Jakarta: Universitas Indonesia (UI-Press).

Reinhartz, J., \& Beach, D. M. (2004). Educational leadership: Changing school, changing roles. Boston: Pearson Educations, Inc.

Starratt, R. J. (1995). Leaders with vision, the quest for shool renewal reworking of: Transforming Life in School (Terjemahan Y.Triyono, SJ dan Henrikus Tugimin Sasminto) Yogyakarta: Kanisius.

Sumidjo, W. (2012). Kepemimpinan kepala sekolah. Jakarta: PT Raja Grafindo Persada

Usman, H. (2011). Manajemen teori, praktik, dan riset pendidikan. Jakarta: Bumi Aksara

Wahab, A. A. (2008). Anatomi organisasi dan kepemimpinan pendidikan. Bandung: Alfabeta

Wuradji. (2009). The educational leadership, kepemimpinan transformasional. Yogyakarta: Gama Media. 